Goldschmidt 2021 Abstract

https://doi.org/10.7185/gold2021.5797

\section{Occurrences of polymetallic nodules in European seas - preliminary results of the MINDeSEA project}

\author{
PEDRO LOPES FERREIRA ${ }^{1}$, F. JAVIER GONZÁLEZ ${ }^{2}$, \\ THOMAS KUHN ${ }^{3}$, JOHAN NYBERG ${ }^{4}$, CARSTEN \\ RUEHLEMANN $^{3}$, CATARINA MONIZ ${ }^{5}$ AND VITOR \\ MAGALHÃES ${ }^{6}$ \\ ${ }^{1}$ Laboratório Nacional de Energia e Geologia \\ ${ }^{2}$ Geological Survey of Spain (IGME) \\ ${ }^{3}$ Federal Institute for Geosciences and Natural Resources (BGR) \\ ${ }^{4}$ Geological Survey of Sweden (SGU) \\ ${ }^{5}$ National Laboratory of Energy and Geology (LNEG) \\ ${ }^{6}$ Portuguese Institute for Sea and Atmosphere (IPMA) \\ Presenting Author: pedro.ferreira@lneg.pt
}

MINDeSEA $^{1}$ (Seabed Mineral Deposits in European Seas: Metallogeny and Geological Potential for Strategic and Critical Raw Materials) is a GeoERA (Establishing the European Geological Surveys Research Area to deliver a Geological Service for Europe) funded project (https://geoeramindesea.wixsite.com/mindesea). The project focuses on an integrative metallogenetic study of the principal types of marine mineral resources (polymetallic sulphides, ferromanganese crusts, phosphorites, marine placers and polymetallic nodules) in the seabed under the jurisdiction of European coastal States and, presently, is compiling data and genetic models for all these deposit types based on extensive studies carried out previously.

Currently, the MINDeSEA database has listed a total of 296 polymetallic nodules occurrences. The majority is located in the Baltic Sea (183 occurrences, corresponding to $62 \%$ of the total), whereas the rest of the registered occurrences are distributed among NE Atlantic Ocean, Macaronesia, Bay of Biscay and Iberian Coast regions.

All polymetallic nodules in the Baltic Sea have low $\mathrm{Mn} / \mathrm{Fe}$ ratios (0.05-2), reaching maximum $\mathrm{Mn}$ concentrations of $\approx 40$ $\mathrm{wt} \%$ and having a gradual variation in Co (0.002-0.05 wt $\%)$ and $\mathrm{Ni}+\mathrm{Cu} \quad(0.005-0.09 \quad \mathrm{wt} \%)$ concentrations. The $\mathrm{REE}^{\mathrm{T}}$ concentrations are between 100 and $700 \mathrm{ppm}$. The abundant nodule occurrence in all different basins and water depths in the Baltic Sea suggests variable processes of nodule formation depending on their environment of formation, but most of them were formed by diagenetic processes with minor influence of hydrogenetic processes.

Relationships shown in the $\mathrm{Fe}-\mathrm{Mn}-(\mathrm{Co}+\mathrm{Ni}+\mathrm{Cu})$ ternary diagram indicate: 1) nodules from the Edoras Bank and Loch Fyne (NE Atlantic Ocean), reveal the influence of two main genetic processes, hydrogenetic and diagenetic, with some samples localized in the mixed region; 2) nodules from Galicia Bank area (Bay of Biscay and Iberian Margin region), show a dominant diagenetic origin, with great contents of $\mathrm{Mn}$ or $\mathrm{Fe}$ and some hydrogenetic and geothermal fluids influence.

Relationships among several REEs from Hormigas Ridge (Gulf of Cadiz) nodules highlights the hydrocarbon seeps influence on their generation, probably related to the presence of mud volcanoes in the region.

[1] This project has received funding from the European Union's Horizon 2020 research and innovation programme under grant agreement No 731166 